\title{
EL VALOR JURÍDICO ASIGNADO POR LA JURISPRUDENCIA DEL TRIBUNAL CONSTITUCIONAL AL DERECHO CONVENCIONAL INTERNACIONAL DE LOS DERECHOS HUMANOS Y SU FUERZA NORMATIVA EN EL PERIODO 2006-2013*
}

\author{
THE LEGAL VALUE ASSIGNED BY THE JURISPRUDENCE OF THE \\ CONSTITUTIONAL COURT TO INTERNATIONAL CONVENTIONAL \\ LAW OF HUMAN RIGHTS AND ITS NORMATIVE FORCE OVER THE \\ PERIOD 2006-2013
}

\section{Humberto Nogueira Alcalá**}

\begin{abstract}
RESUMEN: El artículo analiza la jurisprudencia del Tribunal Constitucional en relación a la fuerza normativa del derecho internacional convencional de derechos humanos ratificado y vigente por el Estado chileno, como asimismo, su consideración de los derechos esenciales asegurados por dichos tratados, en el periodo transcurrido desde 2006 hasta 2013.
\end{abstract}

Palabras clave: Jurisprudencia del Tribunal Constitucional, derechos esenciales, derecho convencional internacional de derechos humanos, parámetro de control de constitucionalidad, fuerza normativa de tratados de derechos humanos

\begin{abstract}
The article analyses the case law of the Constitutional Court in relation to the normative force of conventional international law of human rights ratified and in force by the Chilean State, as also its consideration of essential rights secured by those treaties, in the period from 2006 up to the present day.
\end{abstract}

Key words: Case-law of the Constitutional Court, Essential rights, Conventional international law of human rights, Parameter of constitutionality, Normative force of human rights treaties

\footnotetext{
"Este artículo es parte del proyecto de investigación Fondecyt Regular No 1110016 - 2011 sobre "Análisis de las sentencias del Tribunal Constitucional sobre utilización del derecho constitucional extranjero y del derecho internacional de los derechos humanos y sus implicancias para el parámetro de control de constitucionalidad" del cual el autor es investigador principal.

" Doctor en Derecho. Profesor Titular de Derecho Constitucional, Universidad de Talca. Director del Doctorado en Derecho de la Universidad de Talca. Presidente de la Asociación Chilena de Derecho Constitucional. Vicepresidente del Instituto Iberoamericano de Derecho procesal constitucional. Presidente Capítulo Chileno del Instituto Iberoamericano de Derecho Constitucional. Miembro Asociado de la Academia Internacional de Derecho comparado. Miembro del Consejo Directivo de la Academia Judicial de Chile. nogueira@utalca.cl
} 


\section{INTRODUCCIÓN}

La Constitución se refiere al derecho convencional internacional en algunas pocas disposiciones, como son las contenidas en los artículos 5 inciso $2^{\circ} ; 32 \mathrm{~N}^{\circ} 15 ; 54 \mathrm{~N}^{\circ} 1$; artículos $93 \mathrm{~N}^{\circ} 1$ y 3 ; y 94.

En el texto de la Constitución chilena no hay norma específica que determine la fuerza normativa del derecho convencional internacional ni el derecho convencional de los derechos humanos en el derecho interno, como asimismo, no hay norma que distinga el tratamiento de los tratados de derechos humanos respecto de los tratados que versan sobre otras materias.

El texto constitucional solo tiene una mención específica al derecho convencional internacional de derechos humanos en el artículo 5 inciso $2^{\circ}$.

El texto constitucional carece de toda consideración sobre el derecho consuetudinario internacional y respecto de las reglas imperativas de derecho internacional (ius cogens).

El texto constitucional nos lleva a la conclusión de que los tratados internacionales se incorporan válidamente como tales al ordenamiento jurídico chileno, una vez cumplidas las formalidades del caso, las cuales se encuentran determinadas en los artículos $32 \mathrm{~N}^{\circ} 15$, $54 \mathrm{~N}^{\circ} 1$ y $93 \mathrm{~N}^{\circ} 1$ y 3 de la Constitución, pasando a ser normas de derecho positivo interno, sin dejar de ser normas de derecho internacional.

El tema central del artículo es el de concretar un análisis jurídico crítico sobre la jurisprudencia del Tribunal Constitucional referente a la interpretación y aplicación que realiza acerca de la fuerza normativa de los tratados internacionales en nuestro ordenamiento jurídico, aun cuando nuestro centro de atención básico será respecto de los tratados que aseguran y garantizan derechos fundamentales o derechos esenciales de la persona humana, en la medida que al tenor del artículo 5, inciso $2^{\circ}$ de la Constitución: "El ejercicio de la soberanía reconoce como limitación el respeto a los derechos esenciales que emanan de la naturaleza humana”. A cuyo enunciado normativo la reforma constitucional de 1989 agregó una segunda frase: "Es deber de los órganos del Estado respetar y promover tales derechos, garantizados por esta Constitución, así como por los tratados internacionales ratificados por Chile y que se encuentran vigentes".

Analizaremos así la jurisprudencia del Tribunal Constitucional posterior a la reforma constitucional de 2005, la que introdujo significativas modificaciones al sistema de incorporación de tratados al derecho interno en el actual artículo $54 \mathrm{~N}^{\circ} 1$ y al sistema de control de constitucionalidad de tratados en el artículo $93 \mathrm{~N}^{\circ} 1$ y 3 de la Constitución, centrando las consideraciones sobre la fuerza normativa que el Tribunal Constitucional otorga a los tratados internacionales y su ubicación en el sistema de fuentes del derecho chileno. En segundo lugar, se analiza si el Tribunal constitucional determina alguna diferenciación sobre la fuerza normativa de los tratados de derechos humanos respecto de los tratados ordinarios. En tercer lugar se determinará si el Tribunal Constitucional en su interpretación y aplicación jurisprudencial distingue entre el tratado como fuente normativa y los "derechos esenciales que emanan de la naturaleza humana" los cuales constituyen al tenor del artículo 5 inciso $2^{\circ}$ de la Carta Fundamental, limitaciones al ejercicio de la soberanía. 


\section{JURISPRUDENCIA DEL TRIBUNAL CONSTITUCIONAL SOBRE INCORPORACIÓN Y FUERZA NORMATIVA DE LOS TRATADOS INTERNACIONALES EN EL PERIODO 2006 - 2013}

Es un dato objetivo de carácter normativo positivo la modificación del artículo 54 de la Carta Fundamental por la reforma constitucional de 2005, que determina como atribución exclusiva del Congreso, en su $\mathrm{N}^{\circ} 1^{\circ}$, primer inciso: "Aprobar o desechar los tratados internacionales que le presentare el Presidente de la República antes de su ratificación. La aprobación de un tratado requerirá, en cada Cámara, de los quórum que corresponda, en conformidad al artículo 66, y se someterá en lo pertinente, a los trámites de una ley”.

Destacamos de la reforma su parte final, ya que ello permite distinguir que el constituyente derivado de 2005, quiso clarificar la distinción entre tramitación de una ley y tramitación por el Congreso de un tratado internacional, siendo en el caso de este último solo para efectos de su aprobación que se somete a los trámites de una ley, no siendo el tratado considerado como ley o precepto legal, tanto por su naturaleza (constituye un enunciado normativo producto de la voluntad de dos o más Estados o sujetos de derecho internacional y no de la voluntad unilateral de un Estado a través de sus órganos colegisladores), como por el hecho de ni tampoco se aprueba con fuerza normativa de ley, sino como tratado, el cual nace en el derecho internacional de donde emana su validez y eficacia y donde el Estado solo determina el procedimiento de su incorporación al derecho interno del mismo, sin alterar su naturaleza, su fuerza normativa y las obligaciones jurídicas que genera para los estados partes.

Asimismo, cabe explicitar que la diversidad de procedimientos de formación interna del consentimiento estatal para la incorporación de un tratado al derecho interno no afecta el hecho de que, una vez que el tratado se incorpora válidamente al derecho chileno, este se sitúa fuera del alcance de la capacidad de decisión unilateral del Estado, como claramente lo explicita el artículo $54 \mathrm{~N}^{\circ} 1$ inciso $5^{\circ}$ de la Constitución en conformidad con el derecho internacional, especialmente los artículos 26, 27 y 31.1 de la Convención de Viena sobre Derecho de los Tratados. Ello determina que en los enunciados normativos convencionales el acuerdo de las partes no solo es necesario para su formalización sino también para su suspensión, reforma o pérdida de vigencia. Así los tratados tienen una rigidez en su fuerza normativa y las consecuencias jurídicas que de ellas emanan para los estados partes que los distinguen de todo tipo de norma jurídica de generación unilateral por parte de la voluntad estatal, todo ello con independencia del o de los procedimientos internos que utilice o determine el Estado para formalizar su incorporación al derecho estatal ${ }^{1}$, como es el quórum de aprobación por el Congreso.

El Tribunal Constitucional, reconoce en sus fallos la diferencia de naturaleza jurídica entre ley y tratado, en efecto, en sentencia Rol No 1.288-2008, de 25 de agosto de 2009, en su considerando 420, señalando: "[...] el tratado internacional no es propiamente una ley, pues no se somete al mismo procedimiento que ella, sino que se rige, por lo menos en su formación, por las voluntades de dos o más Estados”.

Balaguer (2012) pp. 143-144. 
Agregando en el mismo considerando que: "En atención a lo anterior es que la Carta Fundamental precisa que las disposiciones de un tratado no podrán ser derogadas, modificadas o suspendidas sino "en la forma prevista en los propios tratados o de acuerdo a las normas generales de derecho internacional" (artículo 54, No 1, inciso quinto). Con ello, además, se reconoce la intervención del derecho internacional tanto en la formación como en la derogación de los tratados".

Esta perspectiva obliga al Tribunal Constitucional, en su sentencia Rol No 1.2882008, en su considerando $56^{\circ}$, a precisar "Que, conforme a las disposiciones constitucionales ya mencionadas, lo que el Estado de Chile no puede hacer es, por ley, derogar las disposiciones de un tratado, pues este es un acuerdo entre dos Estados, a diferencia de la ley que es una manifestación de la soberanía de un solo Estado”.

El Tribunal Constitucional asume en tales considerandos de la sentencia señalada que, por la naturaleza jurídica del tratado el Estado no puede, unilateralmente, modificar, derogar o suspender las disposiciones de un tratado válidamente incorporado al derecho interno, por lo cual el Estado se encuentra sometido a las reglas del derecho internacional para modificar, para suspender o para dejar sin efecto la fuerza normativa de las disposiciones convencionales, como el propio Tribunal Constitucional determina correctamente de conformidad con el artículo $54 \mathrm{~N}^{\circ} 1$, inciso $5^{\circ}$ de la Carta Fundamental.

Asimismo, el Tribunal Constitucional, en referencia a la relación tratado y ley, respecto de su respectiva fuerza normativa en el derecho interno, determina en su sentencia Rol No 804-07 de 28 de diciembre de 2007, considerando $12^{\circ}$ que: “(...) una ley interna contradictoria con el tratado no tiene la aptitud de derogarlo, modificarlo o suspenderlo, por la simple razón de que carece de toda validez, expresando un acto jurídico que se ha producido en contravención a las formas exigidas por la Constitución”.

El Tribunal Constitucional determina así un condicionamiento de la validez de la ley y su aplicabilidad a que ella no se encuentre en contradicción con las normas emanadas de un tratado válidamente incorporado al ordenamiento jurídico.

Aunque no compartimos la concepción expresada en esta sentencia de que el tratado determine la validez de una norma legal, ya que ellas se originan en distintos ordenamientos jurídicos, el primero en el derecho internacional, la segunda en el derecho estatal, lo que determina las reglas pertinentes de validez, materia que no es el objeto de este artículo, si compartimos el principio de que el tratado al entrar en conflicto con la ley interna tiene mayor fuerza normativa o aplicabilidad preferente, por el propio mandato del artículo 54 $\mathrm{N}^{\circ} 1$, inciso $5^{\circ}$, de la Carta Fundamental, que no hace otra cosa que constitucionalizar los artículos 26 y 27 de la Convención de Viena sobre Derecho de los Tratados, los que determinan las reglas jurídicas de cumplimiento de las obligaciones internacionales de buena fe y el deber de no oponer obstáculos de derecho interno al cumplimiento de las obligaciones internacionales como son los tratados. Regla esta última que sin dejar de ser derecho internacional y aplicarse como base de responsabilidad internacional de los Estados por incumplimiento de sus obligaciones, al ser ratificada por el Estado de Chile y ser incorporada a su derecho interno, constituye regla jurídica interna con fuerza normativa que obliga a todos los órganos y autoridades estatales, sin olvidar que ella es el fundamento del inciso $5^{\circ}$ del artículo $54 \mathrm{~N}^{\circ} 1$, el cual tiene fuerza normativa constitucional. 
Una posición consistente con la perspectiva reseñada llevaría a sostener que un tratado incorporado válidamente al ordenamiento jurídico debiera tener fuerza aplicativa preferente respecto del derecho interno de creación unilateral del Estado, con la única salvedad de que siempre primará, especialmente en materia de derechos fundamentales y garantías constitucionales, el principio de progresividad y pro homine o favor persona, en caso de conflicto entre el derecho interno y el tratado, teniendo preferencia normativa aquel enunciado o regla de derecho interno o internacional que mejor proteja los derechos o aquel enunciado normativo o regla jurídica que restrinja menos tales derechos. Esta regla se encuentra implícita en el fundamento de nuestro ordenamiento constitucional que afirma la dignidad humana y establece una opción por un Estado al servicio de ella y de los derechos humanos o fundamentales en el marco del bien común, como explicita el artículo $1^{\circ}$ de la Constitución, lo que el Estado de Chile ha transformado en obligación jurídica de obligatorio cumplimiento ante la comunidad internacional, al haber ratificado diversos tratados que aseguran derechos esenciales o fundamentales, entre ellos la Convención Americana sobre Derechos Humanos, en su artículo 29, literal b). Tratado que es parte del ordenamiento jurídico interno desde el momento de su ratificación y vigencia, por lo tanto, de obligatoria utilización, con preferencia sobre las leyes internas, por la judicatura.

Todo lo anterior, sin perjuicio de que el Estado puede, a través de los procedimientos determinados por el derecho internacional general o de acuerdo a las propias reglas de un determinado tratado internacional, denunciar un tratado, si este lo permite, o participar conforme al derecho internacional en su modificación o derogación, todo lo cual es perfectamente coherente y armónico con el artículo $54 \mathrm{~N}^{\circ} 1$, inciso $5^{\circ}$ de la Carta Fundamental y con las obligaciones jurídicas del Estado respecto del derecho internacional y su cumplimiento de buena fe, sin poner obstáculos de derecho interno a ello.

\section{LOS PROBLEMAS DE INTERPRETACIÓN Y APLICACIÓN DE LA FUERZA NORMATIVA DE LOS TRATADOS POR EL TRIBUNAL CONSTITUCIONAL EN EL PERIODO COMPRENDIDO DESDE LA REFORMA CONSTITUCIONAL DE 2005 HASTA EL PRESENTE}

El problema se explicita con la sentencia Rol No 1.288-2008, de 2009, en su considerando 43을 el que precisa: "Que, respecto a la jerarquía de los tratados internacionales, luego de la reforma constitucional de 2005 a que ya se ha hecho referencia, y no obstante haberse precisado y aclarado con la modificación de la frase final del inciso primero del No 1 del artículo 54 de la Constitución (“...se someterá, en lo pertinente, a los trámites de una ley”) que aquellos no son propiamente una ley, como ya lo había por cierto entendido esta Magistratura (Rol No 288), ello no es óbice a que, en cuanto a su rango, este Tribunal ha estimado que deben sujetarse a la Carta Fundamental".

Agregando el fallo en análisis, en su considerando $47^{\circ}$, que: "El reconocer que un tratado internacional no es lo mismo que una ley no impide que estos puedan asimilarse y que ambos queden comprendidos en la categoría de "precepto legal".

Estas afirmaciones hechas por los considerandos 43 y 47 de la sentencia $N^{\circ} 1.288$ 2008 transcritos referentes a la jerarquía de los tratados internacionales, a su rango y ca- 
tegoría de precepto legal parten del error conceptual y del paradigma mental de que los tratados y los distintos tipos de enunciados normativos de derecho interno forman parte de un mismo ordenamiento jurídico y tienen una misma norma superior que determina su producción, validez y vigencia, determinando su respectiva jerarquía, la que sería la Constitución. Ello no es posible de sostenerse jurídicamente, ya que el tratado a diferencia de las leyes, no es una norma generada ni producida por los modos de producción normativa determinados por la Constitución como expresión unilateral de la voluntad estatal, sino que el tratado se genera y adquiere validez conforme a las modalidades de producción del derecho internacional, el que como el propio Tribunal Constitucional ha precisado como hemos visto anteriormente, requiere para su formación y validez de la voluntad de dos o más estados u organismos internacionales, encontrándose fuera de las determinaciones unilaterales de los estados partes del mismo, siendo el derecho internacional el que determina su modo de producción, su validez, su vigencia y su fuerza normativa para los estados partes.

Es erróneo utilizar la expresión "rango de ley" respecto de un tratado, ya que con dicha expresión se hace alusión a las normas que la potestad unilateral del Estado a través de la Constitución otorga a determinados preceptos normativos generados de acuerdo al modo de producción por ella determinados, a través de los órganos colegisladores representativos del cuerpo político de la sociedad. El rango de ley otorga a tales enunciados normativos una determinada fuerza de ley tanto en su dimensión pasiva como activa que se manifiesta en relación a otras fuentes del derecho generadas unilateralmente por el Estado conforme a la Constitución, lo que determina su fuerza normativa superior a la potestad reglamentaria e inferior a la Constitución. La fuerza de ley implica fuerza normativa superior a las normas infralegales generadas unilateralmente por el Estado. Así el rango de ley es el presupuesto necesario para la atribución de la fuerza de ley como asimismo para la asignación de un valor de ley que el ordenamiento jurídico estatal le otorga teniendo presente su posición en el sistema constitucional de normas.

La aplicación de tales conceptos respecto de un tratado internacional es incorrecto, por cuanto, el tratado no nace a la vida jurídica ni se produce conforme a la Constitución estatal, sino conforme al derecho internacional y su modo de producción normativa, el tratado es fuente del derecho internacional, es este el que determina su validez, fuerza normativa, valor y vigencia, no el Estado unilateralmente a través de su ordenamiento jurídico. A ello debemos agregar que no hay norma alguna en el texto constitucional que atribuya alguna jerarquía a los tratados. La Constitución solo determina la incorporación del tratado al ordenamiento estatal de acuerdo al procedimiento precisado constitucionalmente, lo que no le atribuye al Estado ninguna potestad para determinar unilateralmente su validez, su fuerza normativa ni su vigencia.

El procedimiento estatal de incorporación del tratado al derecho interno solo determina la obligación jurídica de los órganos estatales de vincularse por los enunciados normativos contenidos en el mismo, sin poder disponer acerca de su reforma, suspensión o pérdida de vigencia. El Estado solo es libre de determinar si se obliga o no por el tratado en cuento fuente del derecho internacional, una vez válidamente incorporado al derecho interno, la fuerza normativa de tratado vincula a todos los órganos estatales, incluida la potestad constituyente derivada. Esta es la razón por la cual el constituyente de 2005, en sus artícu- 
los 93, inciso primero $\mathrm{N}^{\circ} 1$ y 3 , estatuyó únicamente un control preventivo de constitucionalidad de tratados y determinó coherentemente con sus obligaciones internacionales de los artículos 26 y 27 de la Convención de Viena sobre Derecho de los tratados, la norma del artículo $54 \mathrm{~N}^{\circ} 1$, inciso $5^{\circ}$, que prohíbe a todo órgano estatal derogar, modificar, o suspender las disposiciones de un tratado, acciones las cuales solo pueden desarrollarse conforme a las disposiciones de los mismos tratados o conforme a las reglas generales del derecho internacional. Sin embargo la técnica constitucional empleada nos parece deficiente, ya que debiera haber establecido dicho control de compatibilidad preventivo respecto de todos los tratados y no solo de algunos de ellos, como asimismo dicho control debió ser para todos los casos un control obligatorio ${ }^{2}$, ya que con dicho control nunca un enunciado normativo de un tratado podría entrar en colisión con la Constitución y nunca podría generarse una hipótesis jurídica de ilícito internacional del Estado que generara responsabilidad internacional, ya que incorporado el tratado al derecho interno, por su calidad de tal, tiene una fuerza aplicativa preferente, tanto activa como pasiva, en caso de conflicto con toda norma de generación unilateral del Estado.

Las razones jurídicas señaladas hacen imposible la homologación del tratado en cuanto a su fuerza normativa con la de un precepto legal, como asimismo, impiden su jerarquización como precepto legal, ya que ella puede predicarse solo de normas que emanan de un mismo ordenamiento jurídico.

La razón de fondo de la sentencia constitucional señalada para, pretorianamente, fijar para el tratado internacional la jerarquía y fuerza de ley, tiene por objeto en tal resolución, determinarse para sí mismo también, pretorianamente, al margen del texto constitucional, un aumento de su potestad jurisdiccional, para poder concretar control reparador concreto de constitucionalidad sobre tratados internacionales, como se explicita en el considerando $41^{\circ}$ del fallo analizado: "Que respecto de los tratados internacionales, luego de la reforma constitucional aludida (la del año 2005), esta Magistratura efectúa dos órdenes de controles. [...]. Segundo, un control ex post y concreto -facultativo- de constitucionalidad de una norma de un tratado que, en cuanto "precepto legal", pueda resultar contraria a la Constitución en su aplicación en "cualquier gestión que se siga ante un tribunal ordinario o especial”, esto es, el Tribunal Constitucional puede declarar inaplicable la disposición de un tratado a un caso concreto, conforme a la atribución que le otorga el № $6^{\circ}$ del inciso primero del artículo 93 de la Constitución, arriba transcrito. De este modo, tal como lo ha sostenido el profesor y doctor en derecho Teodoro Ribera, "la validez del tratado deriva de la legitimidad otorgada por la Constitución y es en ese marco y respetando a aquella que el tratado internacional puede tener vigencia interna" (Informe enviado a la Comisión de Constitución, Legislación, Justicia y Reglamento del Senado, de fecha 9 de diciembre de 2006, pág. 7)”.

A su vez, en el considerando 49 de dicha sentencia Rol No 1.288-2008, el fallo sustentado por la mayoría de 6 de los 10 de los ministros del Tribunal Constitucional, esboza

\footnotetext{
2 Fernández (2003) p. 498; Nogueira Alcalá (2005) p. 538; Aldunate (2013) p. 175; Henríquez (2009a). En contra de dicha posición, a favor del control reparador de tratados, Ribera (2007) pp. 89-118; VerdUGO (2011) pp. $449-477$.
} 
como fundamento para otorgar la fuerza de precepto legal de los tratados con el objeto de posibilitar el control reparador concreto de constitucionalidad de los tratados, que: "Pues bien, si se requirió reformar la Constitución para poder suscribir un tratado que podía pugnar con ella, es evidente que un tratado internacional tiene rango inferior a ella, rango de ley, y sus preceptos son preceptos legales perfectamente susceptibles de ser requeridos de inaplicabilidad, en la medida que se cumplan los demás requisitos que la Constitución establece para ello".

Tales afirmaciones del fallo del Tribunal Constitucional no tienen apoyo en el texto de la Constitución, ni en el contexto y fin de la reforma de 2005. Como ya hemos señalado, el artículo 93 de la Constitución, en su inciso primero, numerales 1 y 3 solo establece taxativamente como competencia del Tribunal Constitucional realizar control preventivo de constitucionalidad sobre tratados, obligatorio o facultativo, según sea el caso, para impedir todo conflicto normativo entre Constitución y tratados internacionales. El texto constitucional reserva el control reparador de constitucionalidad solo para preceptos legales, vale decir, enunciados normativos que se producen por la voluntad unilateral del Estado conforme al modo de producción determinado por la Constitución en el capítulo $\mathrm{V}$ de ella y que tienen jerarquía, fuerza y valor de ley, como fuentes primarias del ordenamiento de fuentes del derecho chileno, conforme hemos determinado previamente, lo que no es aplicable a los tratados internacionales, lo que constituye un forzamiento que desnaturaliza a estos últimos y genera responsabilidad internacional por el ilícito de incumplimiento de obligaciones jurídicas internacionales del Estado.

Cabe además señalar, la necesaria consideración y aplicación de los principios de unidad, de interpretación sistemática y finalista de la Constitución y de efecto útil de los enunciados constitucionales, si se interpretara que un tratado es equivalente a un "precepto legal", perdería todo sentido y efecto útil la diferenciación clara y tajante que realiza la Constitución en su artículo 93, en sus numerales $1^{\circ}$ y $3^{\circ}$ sobre las atribuciones del Tribunal Constitucional, entre leyes, proyectos de ley, proyectos de reforma constitucional y tratados.

La evidencia normativa del texto constitucional es concluyente. El artículo 93, inciso primero No 1 de la Constitución, señala como atribución del Tribunal Constitucional:

"Ejercer el control de constitucionalidad de las leyes que interpretan algún precepto de la Constitución, de las leyes orgánicas constitucionales y de las normas de un tratado que versen sobre materias propias de éstas últimas, antes de su promulgación".

Asimismo, el artículo 93 en su numeral $3^{\circ}$, también distingue claramente la atribución del Tribunal Constitucional para: "Resolver las cuestiones de constitucionalidad que se susciten durante la tramitación de los proyectos de ley o de reforma constitucional y de los tratados sometidos a la aprobación del Congreso".

Resultaría curioso y fuera de toda lógica jurídica que la Constitución distinga entre tratados, reforma de la Constitución, leyes interpretativas de la Constitución y preceptos legales en los numerales $1^{\circ}$ y $3^{\circ}$ del artículo 93 inciso primero en análisis y después, dando un salto lógico injustificado y sin fundamento constitucional, determine que la distinción hecha por la Carta Fundamental en los numerales 1 y 3, no tiene importancia para el No 6 del mismo inciso primero de artículo 93, ya que para dicha disposición hay que entender que lo que antes se distinguía en detalle entre preceptos legales y tratados ahora no tiene 
importancia ni sentido ya que tratados y preceptos legales son lo mismo, sin importar su naturaleza, su fuerza normativa y su diferente disponibilidad unilateral por parte del Estado, dicho forzamiento del texto constitucional del artículo 93 y de la autoatribución de competencia del Tribunal Constitucional carece de toda seriedad interpretativa.

Finalmente, sobre el punto afirmemos que el único enfoque posible de armonización de la Constitución con el derecho internacional es aquel que posibilita solo control de constitucionalidad preventivo, el control de inaplicabilidad ejercido sobre tratados internacionales genera hipótesis de ilícito internacional por incumplimiento de obligaciones jurídicas convencionales dando lugar a la correspondiente responsabilidad del Estado. Cuando el Tribunal Constitucional, pretorianamente, se autootorga la competencia de control de inaplicabilidad de tratados no establecida en el texto de la Carta Fundamental, rompe el principio de hacer el máximo esfuerzo interpretativo de armonización del derecho internacional y la Constitución y entra en contradicción y una conducta incoherente con su propio enfoque jurisprudencial.

En efecto el Tribunal Constitucional en su sentencia Rol $N^{\circ} 804$, considerandos $4^{\circ}$ y $5^{\circ}$, ha determinado: "En este sentido, la regla de oro en la interpretación internacional está dada por el artículo 31 No 1 de la Convención de Viena, la que ordena que: 'un tratado deberá interpretarse de buena fe conforme al sentido corriente que haya de atribuirse a los términos del tratado en el contexto de estos y teniendo en cuenta su objeto y fin'. Esta regla, a su vez, da aplicación a la norma contenida en el artículo 27 de la misma Convención, según la cual todo tratado en vigor obliga a las partes y debe ser cumplida por ellas de buena fe."

"Que, indudablemente, el intérprete en general y el juez en particular debe realizar los mayores esfuerzos, dentro del ámbito constitucional, para procurar cumplir de buena fe las disposiciones y los fines del tratado, conciliando sus disposiciones con otras normas del Derecho Interno, prefiriendo aquellas interpretaciones que armonicen los derechos y obligaciones que del tratado internacional se derivan con el orden jurídico chileno"3.

El Tribunal Constitucional reiterará en el Rol No 804, considerando $12^{\circ}$, que la autoridad nacional competente, debe dentro del marco constitucional y de sus atribuciones, materializar en debida forma y de buena fe las obligaciones convencionales: “(...) debe realizar todos los esfuerzos posibles, actuando en el marco de sus atribuciones y en la forma que establece la Constitución, para materializar en debida forma y de buena fe las obligaciones contenidas en ella”.

La interpretación conforme a la Constitución que debe realizar el Tribunal Constitucional tiene su límite en la propia norma constitucional, su tarea es de un poder constituido no de un poder constituyente, ya que no le está permitido al operador jurisdiccional adulterar las palabras ni realizar una interpretación contra norma expresa; como asimismo tampoco le está permitido vulnerar el principio de efecto útil de las distinciones de vocablos y conceptos realizados por el texto constitucional, lo que lo hace además inconsistente con su propia jurisprudencia ya mencionada sobre este principio.

${ }^{3}$ Caso Jeannye Meneses Cubides, Sentencia del Tribunal Constitucional, Rol No 804-2007, de fecha 28 de diciembre de 2007, considerando $4^{\circ}$ y $5^{\circ}$. 
Contrastemos la falta de fundamento constitucional de los considerandos analizados con las afirmaciones correctas que el propio Tribunal Constitucional reiteradamente ha manifestado en el sentido de que "no es dable aceptar en la interpretación de la Constitución ni de la ley que sus autores incorporen en sus textos normas superfluas, reiterativas o innecesarias que lejos de contribuir a la clarificación de sus prescripciones, confundan o tornen oscuro o difícil de comprender lo que para el legislador es claro y preciso" ${ }^{\text {. }}$

El Tribunal Constitucional ya había señalado anteriormente que era inaceptable "cualquier interpretación que conduzca a anular o privar de eficacia algún precepto de ella"

En Chile el aforismo de que el Tribunal Constitucional es un poder constituyente en sesión permanente, no es sostenible, viola flagrantemente el artículo 7 de las Bases de la Institucionalidad, las cuales, como el propio Tribunal Constitucional ha señalado, irradian todo el ordenamiento jurídico. El Tribunal Constitucional es un órgano constituido con competencias taxativamente determinadas en el artículo 93 de la Carta Fundamental, que no puede extender discrecionalmente según su voluntad, ya que ello vulnera el inciso $2^{\circ}$ del señalado artículo 7 de la Constitución, que expresa textualmente: "Ninguna magistratura, ninguna persona ni grupo de personas pueden atribuirse, ni aun a pretexto de circunstancias extraordinarias, otra autoridad o derechos que los que expresamente se les hayan conferido en virtud de la Constitución o las leyes".

Como establecen tres de los cuatro ministros con votos disidentes del fallo No 1.288-2008, en análisis, en el literal p), de su disidencia, la Ministra de Relaciones Internacionales, señora Soledad Alvear, ya en la tramitación del proyecto de reforma constitucional de 2005 en el Senado en su primer trámite constitucional, había señalado el objeto y fin de armonizar el texto constitucional con las obligaciones jurídicas internacionales del Estado en materia de tratados, precisando al respecto: "El texto de la Constitución regula el proceso de celebración de un tratado internacional, estableciendo las competencias de los distintos órganos del Estado en esta materia (fundamentalmente, del Presidente de la República y el Congreso Nacional), pero nada dice respecto de la derogación o modificación de un tratado, lo que ha suscitado algunos problemas de interpretación, especialmente respecto a la relación entre estos y las leyes posteriores que se pudieren promulgar y que fueren incompatibles con dichos tratados. Parece necesario, dijo, regular estos aspectos puesto que se requiere resolver claramente el problema de la primacía de los tratados internacionales en relación con las normas legales del Estado, evitando que una ley posterior pueda derogar o modificar un tratado existente. Señaló que este tema debería resolverse haciendo consistente la solución de un conflicto entre normas internacionales e internas, dando primacía a las primeras, como lo establece el Derecho Internacional (artículo 27 de la Convención de Viena sobre Derecho de los Tratados), evitando, además, que el Estado incurra en permanentes e, incluso, a veces involuntarias situaciones generadoras de responsabilidad internacional." (Senado de la República. Informe de la Comisión de Constitución, Legislación, Justicia y Reglamento, 6 de noviembre de 2001, p. 332-333.)

\footnotetext{
${ }^{4}$ Sentencia del Tribunal Constitucional chileno, Rol No 325 de 26 de junio de 2001, considerando 47.

5 Sentencia del Tribunal Constitucional chileno, Rol No 33, de 20 de agosto de 1985, considerando $19^{\circ}$ : LOC Tribunal Calificador de Elecciones.
} 
Así lo afirmó también el Supremo Gobierno de la Nación, como órgano colegislador, luego de haber actuado como parte del poder constituyente instituido de 2005, a través de Ministerio Secretaría General de la Presidencia en el debate sostenido a propósito del segundo Informe de la Comisión de Constitución, Legislación y Justicia del Senado, sobre el artículo 47 b) del proyecto de Ley Orgánica Constitucional del Tribunal Constitucional. En efecto, como señala el señor Subsecretario de dicha Cartera, Edgardo Riveros, en el debate parlamentario: "En esa oportunidad, la decisión política del constituyente fue instalar el control preventivo de constitucionalidad sobre determinados instrumentos internacionales que en adelante sometiera el Presidente de la República a la aprobación del Congreso Nacional. No se pretendió dar a la reforma un efecto retroactivo ni general, porque los efectos de las sentencias dictadas por el Tribunal Constitucional en las cuestiones de inaplicabilidad e inconstitucionalidad podrían dejar sin aplicación las disposiciones de un tratado para uno o más casos determinados, en una primera etapa, y las derogarían, en la siguiente.

"Es evidente que esos efectos son incompatibles con el Derecho de los Tratados, establecido en la Convención de Viena de 1969, puesta en vigor en nuestro país mediante el decreto $N^{\circ} 381$, del Ministerio de Relaciones Exteriores, de 1981. Lo anterior cobra mayor relevancia si se tiene en consideración que nuestro país, al ratificar dicha Convención, hizo una reserva declarando su adhesión al principio general de inmutabilidad de los tratados.

"Una sentencia del Tribunal Constitucional chileno que deje sin efecto un tratado internacional entraría en franca colisión con el artículo 27 de la Convención de Viena recién citada, según el cual una parte no podrá invocar las disposiciones de su derecho interno como justificación del incumplimiento de un tratado.

"En consecuencia, este artículo 47 B, y la indicación que plantea su supresión, deben ser examinados adoptando una óptica coherente con las relaciones internacionales de Chile".

En virtud de dichas consideraciones y teniendo presente el artículo $54 \mathrm{~N}^{\circ} 1$, inciso $5^{\circ}$ de la Constitución, cuatro ministros del Tribunal Constitucional consideran que los fundamentos del fallo entran en colisión con la última disposición citada, ya que el control de constitucionalidad concreto de un tratado implica la suspensión de su aplicación para el caso concreto, vulnerando dicho artículo, además de generar responsabilidad internacional.

El Tribunal Constitucional abandona la perspectiva reseñada y analizada críticamente de la sentencia Rol No 1.288-2008, retomando la perspectiva asumida en la sentencia rol $\mathrm{N}^{\circ} 346$ de 8 de abril de 2002, en el considerando duodécimo de la sentencia roles $\mathrm{N}^{\circ}$ 2387-12-CPT y 2388-12-CPT acumulados, de 23 de enero de 2013, en la que afirma la "jerarquía” supralegal de los tratados internacionales, con cita expresa al rol № 346 y a la posición que había afirmado el Tribunal Constitucional en aquella ocasión asumiendo la posición sostenida por el profesor Alejandro Silva Bascuñán al interior de la Comisión de Estudios de la Nueva Constitución, citándolo: "Precisamente esta fue la conclusión sentada por este Tribunal Constitucional en la sentencia Rol No 346, al pronunciarse sobre la constitucionalidad del Estatuto de Roma que creó la Corte Penal Internacional, oportunidad en la que, haciendo suya la tesis explicada por el profesor Alejandro Silva Bascuñán, en la Comisión de Estudio de la Nueva Constitución, se sostuvo que: "En esta forma queda consagrada la jerarquía normativa de los tratados, que es inferior a la de la Carta Fundamental, 
pero superior a cualquiera otra norma jurídica y que las afirmaciones anteriores conservan, a mi juicio, pleno valor, incluso respecto de los tratados sobre derechos humanos esenciales".

Así la sentencia roles No 2387-12-CPT y 2388-12-CPT acumulados, de 23 de enero de 2013, asumida por la unanimidad de los ministros participantes en el fallo del Tribunal Constitucional, estaría sosteniendo ahora en forma pacífica que los tratados se encuentran “jerárquicamente" sobre la ley.

Esta tesis no la compartimos, ya que por las razones ya antes señaladas en este artículo, sostenemos que los tratados tienen fuerza normativa superior al derecho doméstico una vez válidamente incorporados al derecho interno. Primero, porque una interpretación sistemática de la Constitución en sus artículos $54 \mathrm{~N}^{\circ} 1$, inciso $5^{\circ}$ y 93 inciso primero, No $1^{\circ}$, y $3^{\circ}$ no permiten sostener la posición asumida por el tribunal, ya que al efecto la Constitución solo contempla control preventivo de constitucionalidad de tratados en el texto constitucional, lo que solo indica la voluntad de que no haya contradicción entre la Constitución y el derecho internacional ratificado y válidamente incorporado al derecho interno con el objeto de que no exista hipótesis de responsabilidad internacional por ilícito internacional por parte del Estado chileno, como lo explicita la Ministra Soledad Alvear al momento de fundamentar la reforma constitucional de 2005 al artículo $54 \mathrm{~N}^{\circ} 1$ de la Constitución, como lo explicitan los Ministros disidentes de la sentencia de 2009. Tampoco puede sustentarse la posición del Tribunal Constitucional en ninguna disposición del texto constitucional, ya que ninguna establece la jerarquía de los tratados. Asimismo, hablar de jerarquía presupone enunciados normativos que emanan de un mismo ordenamiento jurídico, lo que no es predicable de los tratados respecto del derecho interno del Estado y porque la fuerza normativa del tratado válidamente incorporado al derecho interno impide que cualquier acto de órganos del Estado parte afecten su fuerza normativa aplicativa pasiva y activa, la que solo puede ser afectada conforme a las normas del propio tratado o conforme a las reglas generales del derecho internacional por mandato constitucional del artículo $54 \mathrm{~N}^{\circ} 1$, inciso $5^{\circ}$.

Con el enfoque pretoriano del Tribunal Constitucional de la sentencia roles No 2387-12-CPT y 2388-12-CPT acumulados, de 23 de enero de 2013, de otorgar al tratado rango o jerarquía superior a la ley, el Tribunal Constitucional se queda sin argumentos jurídicos para sostener su autoatribuida competencia de control reparador concreto de constitucionalidad, en virtud de que el tratado tendría fuerza de ley. Una posición coherente y consistente del Tribunal Constitucional con la sentencia de enero de 2013, necesariamente debe llevarlo a abandonar la perspectiva del control de constitucionalidad reparador concreto de tratados internacionales, ya que ellos asumirían una jerarquía supralegal e infraconstitucional, lo que obliga a abandonar la tesis de su fuerza de ley, si no ocurre ello, habría una inconsistencia e incoherencia del Tribunal Constitucional en sus fallos al sostener la fuerza normativa y "jerarquía” superior de los tratados sobre las leyes, para luego sostener contradictoriamente que el tratado es un precepto con "fuerza de ley", lo que es lógicamente insostenible.

Pareciera que el Tribunal Constitucional no ha asumido aún el real sentido y alcance que implica la incorporación del artículo $54 \mathrm{~N}^{\circ} 1$, inciso $5^{\circ}$ de la Constitución, el que obliga a otorgar la fuerza normativa a los tratados exigida por la Constitución mientras ellos 
no sean modificados, suspendidos o dejados sin efecto conforme al derecho internacional. Dicha regla constitucional habilita una interpretación de los tratados válidamente incorporados al derecho interno que imposibilita la suspensión de su fuerza normativa mientras no sean invalidados conforme al derecho internacional. Ello impide al Estado ejercer su potestad pública unilateral para poner obstáculos al cumplimiento de los tratados válidamente incorporados al ordenamiento jurídico, incluida en tal limitación la potestad de reforma constitucional, salvo que ella implique la eliminación del artículo $54 \mathrm{~N}^{\circ} 1$, inciso $5^{\circ}$ de la Carta Fundamental.

\section{LOS TRATADOS DE DERECHOS HUMANOS Y LOS DERECHOS ESENCIALES ASEGURADOS POR TRATADOS INTERNACIONALES EN LA JURISPRUDENCIA DEL TRIBUNAL CONSTITUCIONAL}

El Tribunal Constitucional se ha referido expresamente a la materia de tratados de derechos humanos en el fallo roles No 2387-12-CPT y 2388-12-CPT acumulados de 23 de enero de 2013, asumiendo una perspectiva estrictamente formalista, en su considerando undécimo, recordando el criterio vertido en la sentencia rol No 46 de 1987, donde había determinado que el capítulo, en ese entonces XIV de la Constitución, actualmente capítulo $\mathrm{XV}$, sobre reforma constitucional, "quedaría parcialmente sin sentido si por la vía de los tratados internacionales de derechos humanos se pudiera enmendar su texto (considerando $70^{\circ}$ ), con lo cual descartó la tesis de que a tales tratados pudiera reconocérseles rango constitucional”.

El Tribunal Constitucional en dicha sentencia, reflexiona sobre el inciso $2^{\circ}$ del artículo 5 de la Constitución reformado en 1989, con posterioridad al fallo rol $\mathrm{N}^{\circ} 46$ de 1987, incorporándole la segunda oración al inciso, el que reproducimos: "El ejercicio de la soberanía reconoce como limitación el respeto de los derechos esenciales que emanan de la naturaleza humana. Es deber de los órganos del Estado respetar y promover tales derechos garantizados por esta Constitución, así como por los tratados internacionales ratificados por Chile y que se encuentran vigentes".

El Tribunal Constitucional, en su considerando duodécimo de la sentencia en análisis, reflexiona sobre dicho artículo 5 inciso $2^{\circ}$ señalando que: "Si bien se mira, esa obligación o deber les correspondería a los órganos del Estado de Chile aunque esa norma específica no existiera, en virtud del principio internacional pacta sunt servanda-que se deriva del artículo 26 de la Convención de Viena sobre el Derecho de los Tratados-, que obliga a todos los órganos del Estado parte a cumplir, de buena fe, las obligaciones adquiridas en virtud del tratado, sin admitir excusas fundadas en la aplicación del derecho interno (artículo 27 de la Convención de Viena)".

Agregando en el mismo considerando: "Lo que hace, entonces, esa norma constitucional es reforzar, mediante un enunciado específico, esa obligación en materia de derechos humanos, pero no tiene la virtud de elevar - ni podría hacerlo, ya que no fueron aprobados en ejercicio del Poder Constituyente- tales tratados a rango constitucional" [sic].

Considero que los principios pacta sunt servanda y la inadmisión de excusas fundadas en la aplicación del derecho interno para incumplir un tratado internacional, el constitu- 
yente los entiende incorporados al texto constitucional con fuerza normativa de Constitución en el artículo $54 \mathrm{~N}^{\circ} 1$, inciso $5^{\circ}$, de lo contrario no habría establecido dicha norma en la reforma de 2005, si ya estuviere comprendida desde 1989 en el texto constitucional en su artículo 5 , inciso $2^{\circ}$, además de que dichos principios no son solo válidos en materia de tratados que aseguran y garantizan derechos humanos, sino que tienen un carácter amplio y se aplica a cualquier tratado válidamente incorporado al derecho interno, en forma mucho más directa, evidente y clara, que en la interpretación rebuscada que el Tribunal hace en el artículo 5 inciso $2^{\circ}$ de la Constitución.

Lo que hace la reforma constitucional de 1989 al modificar el artículo 5 inciso $2^{\circ}$, al incorporar la segunda oración a dicho inciso, es determinar la obligación jurídica imperativa de todos los órganos del Estado de respetar y promover los derechos esenciales contenidos en los tratados internacionales ratificados y vigentes. La perspectiva de la oración final del artículo 5, inciso $2^{\circ}$, no es formalista como pretende verla el Tribunal Constitucional sino sustancialista o material en su sentencia de enero de 2013. Son los derechos esenciales contenidos en el envase normativo o fuente denominado "tratado internacional" lo que constituye una "limitación al ejercicio de la soberanía" como determina la Constitución Política, en su artículo 5 , inciso $2^{\circ}$, obligando a los órganos estatales a respetarlos y promoverlos. Por otra parte, no está de más señalar que la obligación jurídica constitucional de los órganos y autoridades públicas es la de "respetar" y "promover" tales derechos esenciales asegurados por los tratados ratificados y vigentes, lo que implica realizar todos aquellos actos dentro de las competencias de las respectivas autoridades u órganos para que dichos derechos sean efectiva y realmente ejercidos por las personas, levantando o eliminando todos los obstáculos que se opongan a ello.

El Tribunal Constitucional sigue analizando el artículo 5, inciso $2^{\circ}$, en el fallo de enero de 2013, en el considerando decimotercero: "El deber de respetar los derechos consagrados en tratados internacionales ratificados por Chile y vigentes se refiere al imperativo que pesa sobre los órganos del Estado de hacer cumplir las normas que los contienen cuando estas son suficientemente autónomas para ejecutarse sin necesidad de una regulación adicional. En cambio la obligación de promover los derechos alude a la necesidad de remover los obstáculos que dificulten su libre ejercicio".

En la primera frase del considerando transcrito en negritas el Tribunal Constitucional acierta a especificar que el deber constitucional de los órganos estatales es el de respetar los derechos esenciales contenido en los tratados. Luego se desvía de lo sustantivo que son los derechos esenciales a la lógica formalista de la fuente en que están contenidos los derechos, los tratados, para determinar que el enunciado normativo debe ser suficientemente autónomo o autoejecutable. Cabe señalar que este último aspecto la Constitución no lo deja en la esfera de competencia del Tribunal Constitucional sino que ello corresponde al órgano jurisdiccional que tiene competencia para interpretar y aplicar el tratado que asegura tales derechos en el plano internacional, por ejemplo respecto de la autoejecutividad de los derechos asegurados por la Convención Americana sobre Derechos Humanos la competencia es de la Corte Interamericana de Derechos Humanos, sin perjuicio de lo cual en el ejemplo señalado la Convención asegura y garantiza que el Estado solo debe cumplir, incluso modificando la Constitución si es necesario para ello, conforme a las obligaciones ge- 
nerales determinadas por los artículos 1 y 2 de dicha Convención. El incumplimiento de la obligación de respetar, garantizar y promover los derechos esenciales por parte de cualquier órgano estatal constituye no solo un incumplimiento del deber constitucional imperativo del artículo 5 inciso $2^{\circ}$ de la Constitución, como asimismo del artículo $54 \mathrm{~N}^{\circ} 1$, inciso $5^{\circ}$, sino que genera un acto ilícito internacional por violación de derechos humanos asegurados convencionalmente, generando la consiguiente responsabilidad internacional del Estado por la actuación del órgano infractor.

Es el propio Tribunal Constitucional en sentencia Rol 943-07, de fecha diez de junio de dos mil ocho, el que determina que: "Que, como ya se ha señalado, el contenido del artículo 19 de la Carta Fundamental, conjuntamente con sus artículos $1^{\circ}, 4^{\circ}$ y $5^{\circ}$, inciso segundo, de la misma, configuran principios y valores básicos de fuerza obligatoria que impregnan toda la Constitución de una finalidad humanista que se irradia en la primacía que asignan sus disposiciones a la persona humana, a su dignidad y libertad natural, en el respeto, promoción y protección a los derechos esenciales que emanan de la naturaleza humana, que se imponen como limitación del ejercicio de la soberanía y como deber de los órganos del Estado;

Que estos principios y valores, como ya se recordó -y lo hace manifiesto el inciso segundo del artículo $6^{\circ}$ de la Constitución, que precisa que sus preceptos obligan no solo a los titulares o integrantes de los órganos del Estado sino a toda persona, institución o grupo-, no configuran meras declaraciones programáticas sino que constituyen mandatos expresos para gobernantes y gobernados, debiendo presidir la labor del intérprete constitucional, en cuanto normas rectoras y vitales que coadyuvan a desentrañar el verdadero sentido y espíritu del resto de las disposiciones de la Constitución; Que, por lo recién expresado, debe desecharse toda interpretación de las normas constitucionales que resulte contradictoria con los aludidos principios y valores rectores de la Carta Suprema"6.

Señalemos que el Tribunal Constitucional también ha determinado en sentencia Rol $\mathrm{N}^{\circ}$ 1218-08-INA, de siete de julio de dos mil nueve, que: "Que el sistema institucional vigente en Chile se articula en torno de la dignidad que singulariza a todo sujeto de la especie humana, siendo menester poner de relieve que si la Carta Política asegura a todas las personas los derechos fundamentales, lo hace en el entendido que preexisten a ella; y que, en armonía con lo preceptuado en el artículo $5^{\circ}$, inciso segundo, los órganos públicos y los agentes privados, cada cual en ejercicio de la competencia y facultades que les han conferido, respectivamente, la Constitución y la ley, no solo están obligados a respetar esos derechos, sino que, además, a protegerlos y promoverlos"

El Tribunal Constitucional en su sentencia rol No 1218-08 del año 2009, ha precisado en su considerando $17^{\circ}$ que: "Decimoséptimo. Que de la dignidad, que singulariza a toda persona humana, se deriva un cúmulo de atributos, con los que nace y que

\footnotetext{
${ }^{6}$ Sentencia del Tribunal Constitucional; Rol N ${ }^{\circ}$ Rol 943-07, de 10 de junio de 2008, considerando $30^{\circ}$ al $32^{\circ}$. Las negritas son nuestras.

7 Sentencia del Tribunal Constitucional, Rol N $1218-08$-INA, de 7 de julio de 2009, considerando $18^{\circ}$. Las negritas son nuestras.
} 
conserva durante toda su vida. Entre tales atributos se hallan los derechos públicos subjetivos o facultades que el ordenamiento jurídico le asegura con carácter de inalienables, imprescriptibles e inviolables en todo momento, lugar y circunstancia" ${ }^{\text {. }}$

Si la Constitución asegura, garantiza y promueve derechos esenciales y estos limitan el ejercicio de la soberanía estatal, ellos son tales por su sustancia y no por la fuente formal en que están contenidos. Ello implica que el operador jurídico, cualquiera sea este y el nivel que ocupe en el aparato jurisdiccional del Estado, debe partir por considerar si estamos frente a derechos esenciales y no cuál es el envase normativo en que se encuentran tales derechos, ya que ello es secundario, en la medida que en materia de derechos esenciales debe aplicarse la norma que mejor proteja tales derechos en sus atributos y garantías, vale decir, el principio pro homine o favor persona ${ }^{9}$.

En tal perspectiva se encuentra asimismo la jurisprudencia de la Corte Suprema en nuestro país: "Que en la historia fidedigna del establecimiento de la norma constitucional del artículo $5^{\circ}$ inciso segundo, queda claramente establecido que la soberanía interna del Estado de Chile reconoce como límite los derechos que emanan de la naturaleza humana; valores que son superiores a toda norma que puedan imponer las autoridades del Estado, incluido el propio Poder Constituyente, lo que impiden sean desconocidos (Fallos del Mes No 446, sección criminal, página 2066, considerando 4º" ${ }^{10}$.

En otra sentencia, la Corte Suprema determina: "Que, como lo ha señalado esta misma Corte Suprema en reiteradas sentencias, de la historia fidedigna del establecimiento de la norma fundamental contenida en el artículo $5^{\circ}$ de la Carta Fundamental, queda claramente establecido que la soberanía interna del Estado de Chile reconoce su límite en los derechos que emanan de la naturaleza humana, 'valores que son superiores a toda norma que puedan disponer las autoridades del Estado, incluido el propio poder constituyente, lo que impide sean desconocidos' (S.C.S. 30.1.2006)"11.

Si el Estado ha ratificado tratados internacionales que contienen derechos esenciales, más aún, si el preámbulo del mismo tratado así lo explicita expresamente, el Estado y sus órganos al incorporar válidamente el tratado al ordenamiento jurídico, ha asumido seria y responsablemente sus fundamentos y las obligaciones jurídicas que de ello emana de buena fe, ya que dichas obligaciones han sido asumidas libre y voluntariamente, previo análisis por el Gobierno y por el Congreso Nacional antes de su ratificación, y por tanto, al ratificar el tratado se hace para cumplirlo efectiva y fielmente, obligándose a respetar y garantizar los derechos en él determinados como derechos esenciales derivados de la dignidad humana o atributos propios de la persona humana, los que, de acuerdo al texto expreso de la Constitución, constituyen una limitación del ejercicio de la soberanía y un deber jurídico

\footnotetext{
8 Sentencia del Tribunal Constitucional Rol No $1218-08$-INA, de 7 de julio de 2009, considerandos $17^{\circ}$. Las negritas son nuestras

9 Sobre el principio pro homine, véase Pinto (1997); Bidart Campos (2001); Amaya Villarreal (2005); Nogueira (2006); Ayala (2012).

10 Sentencia de la Corte Suprema, Rol No 469-98, de fecha 9 de septiembre de 1998, citado por CEA EGAÑA (2002) p. 236.

11 Sentencia de la Corte Suprema, Rol No 559-04, de fecha 13 de diciembre de 2006, considerando $22^{\circ}$.
} 
constitucional de todos los órganos estatales el de asegurarlos y promoverlos, no oponiendo obstáculos de derecho interno a tal cumplimiento.

Pongamos nuevamente la evidencia del derecho positivo que constituye la Convención Americana sobre Derechos Humanos, como ejemplo pedagógico en la materia, de la cual citamos una parte de su preámbulo, el que con claridad meridiana determina que los Estados partes: Reafirman "su propósito de consolidar en este Continente, dentro del cuadro de las instituciones democráticas, un régimen de libertad personal y de justicia social, fundado en el respeto de los derechos esenciales del hombre";

Reconocen "que los derechos esenciales del hombre no nacen del hecho de ser nacional de determinado Estado, sino que tienen como fundamento los atributos de la persona humana, razón por la cual justifican una protección internacional, de naturaleza convencional coadyuvante o complementaria de la que ofrece el derecho interno de los Estados americanos";

Consideramos que no puede sostenerse, después de asumir tales principios, una perspectiva formalista, desconociendo la dimensión material o sustantiva que determina que los derechos asegurados y garantizados por la Convención Americana de Derechos Humanos son derechos esenciales y derivados inmediatamente de la dignidad humana, y de ejecución directa e inmediata al tenor de los artículos 1 y 2 de la Convención, ratificado ello por la Corte IDH como intérprete auténtico y final de dicha convención, conforme a sus artículos 62 inciso 1 y 3 , perspectiva que se encuentra también en muchos otros tratados de derechos humanos.

Si tomamos en serio la palabra del Tribunal Constitucional en el fallo de enero de 2013, que determina el deber jurídico constitucional de cumplir el pacta sunt servanda y el principio de buena fe y no oponer obstáculos formales de derecho interno al cumplimiento del imperativo constitucional de asegurar y promover los derechos esenciales, teniendo presente que ello es el objeto central y el fin del artículo 5 inciso $2^{\circ}$ de la Constitución.

Por otra parte, el Tribunal Constitucional ha establecido una metodología para aplicar los atributos y garantías de los derechos esenciales contenidos en tratados internacionales ratificados y vigentes. En efecto ella está claramente establecida en la sentencia rol No 807 de 2007, en la cual el tribunal debe pronunciarse sobre el cuestionamiento de la ley No 18.216, en virtud del derecho a no ser objeto de prisión por deudas, asegurado tanto por la Convención Americana de Derechos Humanos como por el Pacto Internacional de Derechos Civiles y Políticos de Naciones Unidas. El Tribunal Constitucional considera al respecto que "para acoger la acción interpuesta resultaría necesario que se verificara una doble condición: en primer lugar, que existiera contradicción entre el artículo 19 de la Ley No 18.216 -o más precisamente entre los efectos que produciría la aplicación de ese precepto en la gestión pendiente- y alguna de las normas de derecho internacional invocadas, y que, además, y en segundo lugar, en virtud de lo establecido en el artículo $5^{\circ}$, inciso segundo, de la Carta Fundamental, tal contradicción habilitara a esta Magistratura para declarar inaplicable el precepto legal".

Ello implica el uso de un test que debiera ser aplicación general y uniforme por el Tribunal Constitucional ante la existencia de una contradicción entre los efectos que produciría la aplicación de un precepto legal y su conflicto con atributos de un derecho 
esencial asegurado por un tratado internacional ratificado y vigente, en virtud de la norma de reenvío del artículo $5^{\circ}$ inciso $2^{\circ}$ de la Constitución, debiendo en tales casos siempre inaplicarse el o los preceptos legales que entraran en conflicto con los atributos del derecho esencial no siendo determinante si dicho derecho esencial se encuentra asegurado por la Constitución o por un tratado internacional ratificado y vigente, como asimismo, si el precepto legal en todas sus aplicaciones posibles es contrario a uno o más derechos esenciales, el Tribunal Constitucional debiera expulsarlo del ordenamiento jurídico conforme a las reglas del artículo 93, inciso primero $\mathrm{N}^{\circ} 7$ de la Constitución. Esta metodología que el Tribunal aplica cada vez que tiene voluntad de hacerlo, lo que obviamente no ocurre cuando evita el análisis de fondo y se queda en el análisis formal de la fuente normativa en que está contenido el derecho lo que no requiere de mucho esfuerzo intelectual. Optar por una u otra perspectiva depende de la sola voluntad de quienes integran el Tribunal Constitucional en cada oportunidad.

En variadas sentencias el Tribunal Constitucional ha asumido que determinados atributos y garantías de derechos asegurados por tratados internacionales por ser derechos esenciales conforman parte del parámetro de control de constitucionalidad de normas infraconstitucionales, de conformidad con el artículo 5 inciso $2^{\circ}$ de la Constitución, como han sido el derecho a la identidad (rol No 834 de 2008 y rol No 1340 de 2009); el derecho a no ser objeto de prisión por deudas (roles N 576 y 807 de 2007; Rol No 1249 de 2008, Rol No 1006 y No 1145 de 2009); el derecho a la presunción de inocencia (roles No 993 y No 1152 de 2008); el derecho de defensa y la reformatio in pejus (rol 1250 de 2008); el derecho a que la sentencia penal sea revisada por otro tribunal igualmente independiente e imparcial (sentencias roles No 986 de 2008; No 821 de 2008; No 1130 de 2008; No 1432 de 2010; No 1443 de 2010; No 1501 de 2010), entre otros casos ${ }^{12}$.

Aceptemos solo por hipótesis que en la Constitución no hay una regla precisa sobre tratados en materia de derechos humanos, lo que inhabilita al Tribunal Constitucional para otorgarle, pretorianamente, sin respaldo en el texto constitucional, fuerza de ley o jerarquía inferior a la Constitución y superior a las leyes a los tratados. Sin embargo, otra cosa distinta es sostener que los derechos esenciales asegurados por tratados internacionales no tienen más que fuerza normativa de ley, ya que ello implica desconocer lisa y llanamente la fuerza normativa de aplicación directa e inmediata de la regla prevista en el artículo $5^{\circ}$ inciso $2^{\circ}$ de la Constitución, que los constituye en limitación del ejercicio de la soberanía.

Por otra parte, cabe determinar que en materia de derechos esenciales la regla de oro son los postulados de progresividad y pro homine o favor persona, como el propio tribunal ha señalado en diversas oportunidades (sentencias roles $\mathrm{N}^{\circ} 1361-09$ de 2009; $\mathrm{N}^{\circ}$ 1484-09 de 2010 y N$^{\circ} 1881-10$ de 2011), regla que es parte de nuestro derecho positivo al haberse incorporado al ordenamiento jurídico nacional la Convención Americana sobre Derechos Humanos, la que contiene en su artículo 29 las reglas de interpretación de derechos, las cuales, según expresiones del propio Tribunal Constitucional son de jerarquía superior a las leyes, lo que en términos castizos implica afirmar que son supralegales, los cuales deben ser necesariamente aplicadas en materia de interpretación de derechos, en virtud del principio

12 Sobre la materia, véase Nogueira (2012a) pp. 149-187. 
de juridicidad determinado por el artículo 6 de la Constitución. Si se es coherente con tales reglas de interpretación de derechos, siempre debe aplicarse la norma que mejor proteja los derechos, asegure más atributos o garantías de ellos, o aquella que los restrinja o limite menos, teniendo las normas limitadoras de derechos un alcance restrictivo, sin poder aplicarse analógicamente a situaciones diferentes. Dichas reglas interpretativas tienen su fundamento en la dignidad de la persona humana y la primacía de los derechos esenciales sobre el ejercicio del poder estatal, en términos estrictamente constitucionales, "la soberanía tiene como limitación los derechos esenciales que emanan de la naturaleza humana".

Asimismo, tampoco puede afirmarse que en Chile no hay cláusula abierta de derechos esenciales o humanos, primero porque ello se encuentra desmentido por los miembros de la Comisión de estudios de la Nueva Constitución (Guzmán, Evans de la Cuadra, Alejandro Silva Bascuñán), para quienes gustan de la Constitución testamento. Ello tampoco puede afirmarse del texto de la Constitución, ya que en ninguna parte se afirma que los derechos esenciales son únicamente los previstos en el artículo 19 de la Constitución y que dicha enumeración es taxativa y cerrada. El propio Tribunal Constitucional acepta en su jurisprudencia la existencia de derechos implícitos, nuevos o de generación jurisprudencial, como determina por ejemplo, en la sentencia Rol No 226 de 30 de octubre de 1995, considerando 25: "(...) la doctrina como nuestra Constitución Política reconocen la existencia de derechos, aunque no estén consagrados en el texto constitucional, a menos que esta consagración implique una violación a las normas fundamentales.

"Esta última expresión significa que los hombres son titulares de derechos por ser tales, sin que sea menester que se aseguren constitucionalmente para que gocen de la protección constitucional”.

En efecto, la doctrina también ha entendido que, desde la reforma constitucional de 1989 al artículo 5 inciso $2^{\circ}$, el catálogo de derechos fundamentales asegurados a las personas no es taxativo, en la medida que no solo considera los derechos explícitamente asegurados por el artículo 19 de la Constitución, "sino que se encuentra complementado por todos aquellos derechos esenciales que emanan de la naturaleza humana recogidos en tratados internacionales ratificados por Chile y vigentes"13.

Por otra parte, si nos quedamos en el texto constitucional positivo, el concepto de derechos esenciales empleado por el artículo 5, inciso segundo, constituye una cláusula abierta que no se remite exclusivamente al artículo 19 de la Constitución. Por otra parte, el Estado al asumir como parte de su derecho interno vinculante la Convención Americana de Derechos Humanos, asume como regla interpretativa de derechos en el artículo 29, literal c), la concepción de derechos implícitos, la cual impide una interpretación en materia de derechos que posibilite "la exclusión de otros derechos y garantías que son inherentes al ser humano o que se derivan de la forma democrática representativa de gobierno".

Si las afirmaciones anteriores son ciertas y forman parte de nuestro ordenamiento jurídico, este contempla reglas de derecho que obligan a resolver los casos conforme a normas que provienen del derecho internacional de los derechos humanos, que se incorporan al

13 Peña (2008) p. 207; también, Vivanco (2006) p. 239; Cea Egaña (2012); Cumplido (1997) p. 95; NogueiRA (1997) p. 23. 
derecho chileno, siendo vinculantes y obligatorias y cuya inaplicación vulneran el artículo 5 inciso $2^{\circ}$; el artículo $54 \mathrm{~N}^{\circ} 1$ inciso $5^{\circ}$, generando conductas contrarias a las exigidas por el texto constitucional, además de generar ilícitos internacionales por vulnerar las obligaciones jurídicas en materia de derechos humanos, dando lugar a responsabilidad internacional del Estado por actos del Estado juez.

Así una conducta del Estado juez coherente con la Constitución y las obligaciones internacionales lo obliga a interpretar y aplicar los derechos esenciales, humanos o fundamentales en virtud de la obligación constitucional determinada en el inciso $2^{\circ}$ del artículo 5 de la Constitución, considerando los estándares mínimos contenidos en el derecho internacional vinculante para el Estado, ya sea como complemento de los atributos de los derechos y garantías de ellos aseguradas constitucionalmente, como es el caso de atributos del derecho al debido proceso (presunción de inocencia; derecho a traducción o intérprete en caso de no hablar el idioma del tribunal; derecho a la asistencia consular si se es extranjero; igualdad de armas; procedimiento sin dilación indebida; sentencia en plazo razonable; derecho a la revisión de la sentencia penal) cuando las normas constitucionales respecto de derechos esenciales se encuentran por debajo de dichos estándares; reconociendo derechos nuevos o implícitos (como el propio tribunal ha establecido en su jurisprudencia con el derecho a la información y el derecho a la identidad) o como reglas de interpretación de derechos esenciales mediante la aplicación de los principios de progresividad y favor persona.

A su vez, si se asume la posición del Tribunal Constitucional de que los tratados internacionales de derechos humanos, como cualquier otro tratado tiene jerarquía superior a las leyes, vale decir supralegal, con la consiguiente fuerza normativa supralegal, y los derechos contenidos en tales tratados deben ser considerados de acuerdo a la fuerza normativa de los tratados que los contienen, se debería asumir lo que el Tribunal Constitucional determina en su fallo rol 804, respecto de la optómetra colombiana, en su considerando $15^{\circ}$, en el cual precisa que, ante la existencia de un conflicto entre un tratado y una ley, sin que exista un problema de constitucionalidad de esta última, el tema queda dentro de las atribuciones de los jueces ordinarios los que deben calificar y decidir sobre la materia: "No existe, de esta manera, un problema de constitucionalidad -oposición sustantiva de la ley a la Constitución-, sino de contraste entre un tratado internacional vigente y una ley nacional, que corresponde calificar y decidir al juez de la instancia”.

En efecto, este enfoque interpretativo nos sitúa en el mismo problema se ha producido en países como Francia, donde conforme al artículo 55 de la Constitución la Corte Constitucional determina la supralegalidad e infraconstitucionalidad de los tratados, negándose a integrar al bloque de constitucionalidad los tratados internacionales, considerando que ellos no integran el parámetro de control de constitucionalidad, entregándole la competencia para determinar la aplicación de los tratados a la jurisdicción ordinaria ${ }^{14}$. En dicha hipótesis los tribunales ordinarios deben aplicar preferentemente el tratado frente a la ley, en otras palabras, deben inaplicar la ley, cuando la norma del tratado, sobre todo si ella se refiere a derechos fundamentales, establece un estándar mínimo superior al consagrado

14 Sentencia de la Corte Constitucional francesa "IVG" (Interruption volontaire de la grosesse), de 15 de enero de 1975. 
en la norma legal, haciendo aplicación del principio favor persona o pro homine, es especial si estamos aplicando la Convención Americana sobre Derechos Humanos o el Pacto Internacional de Derechos Civiles y Políticos de Naciones Unidas, por mencionar solo las convenciones internacionales más importantes que vinculan al Estado chileno. Así lo ha hecho tanto la Corte de Casación ${ }^{15}$ como el Consejo de Estado Francés ${ }^{16}$ en la materia, cuando deben aplicar la Convención Europea de Derechos Humanos, complementada con la jurisprudencia del TEDH de Estrasburgo. En todo caso cabe señalar que, tanto en Francia como en Chile, no hay mecanismo institucional específico que determine el control de dicha superioridad del tratado sobre la ley, sino que ello tanto en Francia como en Chile se concretaría por vía puramente jurisprudencial.

Ello se debe a que el juez nacional es el juez natural que aplica en primer lugar el derecho emanado de la $\mathrm{CADH}$, complementada con la ratio decidendi de las sentencias de la Corte Interamericana de Derechos Humanos, valer decir, realiza control de convencionalidad, en virtud del principio de competencia que el propio Tribunal Constitucional les atribuye, ya que este último se niega a realizar dicho control, ya que ello implicaría aceptar que los derechos esenciales contenidos en tratados de derechos humanos ratificados y vigentes forman parte siempre del parámetro de control de constitucionalidad de los enunciados normativos del derecho interno infraconstitucional, si ellos determinan un estándar superior a la norma legal interna sobre atributos y garantías de derechos, reconociéndose así un bloque de constitucionalidad de derechos fundamentales.

Si ello es así, no se ha reflexionado que esta perspectiva genera un posible conflicto sin posibilidad de resolución entre el Tribunal Constitucional y los tribunales ordinarios de justicia.

En esta realidad, forjada por la propia jurisprudencia del Tribunal Constitucional, se establece un control reparador o sucesivo de constitucionalidad de leyes de competencia del Tribunal Constitucional y un control igualmente reparador o sucesivo de convencionalidad practicado por la jurisdicción ordinaria, administrativa y otras especiales, en base a los tratados que aseguran derechos fundamentales. Ello puede producir parámetros disímiles de control de la ley por el Tribunal Constitucional y por los jueces ordinarios, lo que puede llevar a que el Tribunal constitucional considere una ley conforme a la Constitución y la jurisdicción ordinaria la pueda considerar inconvencional por afectar el derecho a un proceso justo. Es el caso que se dio en Francia cuando la Corte Constitucional considera conforme a la Constitución una ley que luego fue inaplicada por inconvencional por la Corte de Casación por considerarla contraria al artículo 6 de la Carta Europea de Derechos Humanos, teniendo en consideración la interpretación del mismo dada por el TEDH en el caso Zielinski y otros de 28 de octubre de $1999^{17}$.

\footnotetext{
15 Sentencia de la Corte de Casación francesa en caso Societé des cafés Jacques Vabré, de 24 de mayo de 1975.

16 Sentencia del Consejo de Estado "Nícolo", de 20 de octubre de 1998; Sentencia "Moussa", de 30 de octubre de 1988. Esta jurisprudencia superó la resistencia que hasta dicho fecha concretó el Consejo de Estado a realizar control de convencionalidad. Sobre la materia, véase Silva (2006) p. 211.

17 Véase Jimena (2013) p. 44.
} 
Tal perspectiva genera las dificultades de dos jurisdicciones constitucional y ordinaria con eventuales criterios diferentes de interpretación y aplicación de derechos asegurados por tratados internacionales.

Otra hubiere sido la realidad si el Tribunal Constitucional asumiera los derechos esenciales asegurados por tratados internacionales en el bloque de constitucionalidad, incorporando a este los atributos y garantías que integran los derechos asegurados por tratados internacionales ratificados y vigentes, ya que en tal perspectiva, los jueces ordinarios deberían ocurrir ante el Tribunal Constitucional, en virtud del artículo $93 \mathrm{~N}^{\circ} 6$ de la Carta Fundamental que establece la acción de inaplicabilidad por inconstitucionalidad en control reparador o sucesivo concreto.

\section{CONSIDERACIONES FINALES}

Analizada la jurisprudencia del periodo 2006 hasta la actualidad, periodo en que ha operado el Tribunal Constitucional con la nueva integración y competencias determinada por la reforma constitucional de 2005, la cual también modificó el artículo $54 \mathrm{~N}^{\circ} 1$, inciso $5^{\circ}$ de la Constitución, referente al procedimiento de aprobación de tratados internacionales, es posible obtener algunas conclusiones acerca del tratamiento y fuerza normativa asignada a los tratados ratificados y vigentes referentes a derechos humanos, como asimismo, acerca de los derechos esenciales contenidos en dichos tratados.

La primera conclusión es la inexistencia de una línea jurisprudencial de carácter permanente y estable acerca de la fuerza normativa de los tratados internacionales sean o no referentes a derechos humanos, ya que la jurisprudencia pese a tener aspectos de continuidad en el periodo en que asume la diferencia de naturaleza, procedimiento de aprobación y cualidades específicas en términos de su incorporación al derecho interno y no disponibilidad unilateral por parte del Estado parte respecto de los tratados internacionales, ella varía en relación a la fuerza normativa otorgada a tales tratados, oscilando entre aquellas sentencias que asimilan los tratados a los preceptos legales otorgándoles valor y fuerza de ley y aquellas que les reconocen una jerarquía superior a las leyes e infraconstitucional. En otras oportunidades, se abandona la dimensión formal y se reconoce los atributos y garantías de derechos esenciales contenidos en tratados como parte del parámetro de control de constitucionalidad de normas infraconstitucionales.

Las perspectivas reseñadas varían a través del tiempo, como hemos podido determinar en el cuerpo de este artículo. Asimismo, cuando el Tribunal una aproximación formal, parte de los conceptos de jerarquía y de validez en relación al derecho convencional internacional como si la Constitución fuera el fundamento de validez tanto de los tratados como de la ley, y la Constitución determinara la fuerza normativa de los tratados internacionales en forma unilateral, ignorando que en el caso de los tratados internacionales su fundamento de validez se encuentra en el derecho internacional y no en el derecho interno, no estando disponibles en su validez y vigencia a las decisiones unilaterales del poder estatal, pudiendo estas últimas generar responsabilidad internacional del Estado por incumplimiento de las obligaciones convencionales las cuales vinculan a todos los órganos estatales. Así la doctrina emanada de las sentencias del Tribunal Constitucional no logran integrar la 
fuerza normativa de los tratados en una perspectiva que armonice el enfoque de derecho interno con el de derecho internacional, sin perjuicio de poder constatar un desacuerdo al interior del Tribunal Constitucional sobre los alcances de las obligaciones que genera para el Estado Juez el artículo $54 \mathrm{~N}^{\circ} 1$, inciso quinto de la Carta Fundamental introducido por la reforma constitucional de 2005.

A su vez, en la jurisprudencia del periodo analizado es posible constatar una ausencia de una dogmática compartida y pacífica acerca de la determinación del concepto de derechos esenciales y de su carácter de limitación al ejercicio de la soberanía o potestad estatal.

En algunos casos el Tribunal Constitucional asume tales derechos esenciales que se aseguran en tratados internacionales como parte del parámetro de constitucionalidad por vía del segundo inciso del artículo 5 de la Constitución, cuando se asumen atributos de tales derechos esenciales que no están expresamente asegurados constitucionalmente, como es el caso del derecho a la identidad, el derecho a la presunción de inocencia, del derecho a la revisión de la sentencia penal, del derecho a no ser privado de libertad por deudas, para señalar algunos casos específicos. Asimismo, el Tribunal Constitucional ha diseñado una metodología cuando discrecionalmente determina asumir un análisis sustantivo de los derechos (sentencia rol No 807 de 2007).

En otros casos, se prescinde de la categoría de derechos esenciales y de la metodología para la determinación de la integración del parámetro de control de constitucionalidad antes señalado y se engloba a dichos derechos en un enfoque que confunde el contenido con el continente, los derechos esenciales con la norma formal que los asegura, en esta segunda perspectiva, se asimilan los derechos esenciales a la categoría formal que el Tribunal pretorianamente le otorga a los tratados y, por tanto, asimila los derechos esenciales asegurados por ellos a la fuerza normativa infraconstitucional y jerarquía supralegal si asumimos determinados fallos (sentencias rol No 346 de 8 de abril de 2002 y roles No 2387-12-CPT y 2388-12-CPT acumulados de 23 de enero de 2013); o simplemente con fuerza de ley si asumimos otros fallos (Rol No 1.288-2008 de 25 de agosto de 2009); aunque una ley contraria a un tratado sería inválida según otros fallos del mismo tribunal (sentencia Rol No 804-07 de 28 de diciembre de 2007), sin que haya una línea estable y coherente a través del tiempo sobre la materia. Ello posibilita en virtud del ámbito de competencia trazado por el Tribunal Constitucional un control del texto formal de la Constitución por el Tribunal Constitucional y un control de convencionalidad por los tribunales ordinarios y especiales, con la consiguiente consecuencia de criterios dispares en ambas jurisdicciones

Con el objeto de evitar la inseguridad jurídica que se presenta por la variabilidad de criterios antes señalados de parte de la judicatura constitucional y los paradigmas mentales de sus operadores, consideramos conveniente incorporar a la Constitución formalmente e inequívocamente el control preventivo obligatorio de todos los tratados internacionales, luego de su aprobación por el Congreso Nacional y antes de su ratificación por el Presidente de la República, posibilitando incluso una acción popular en la materia durante la tramitación del tratado por el Congreso Nacional con el objeto de posibilitar la eventual participación de la ciudadanía en la impetración del control para evitar la introducción de normas conflictuadas con el texto constitucional. Además debe explicitarse inequívocamente, como lo hacía la reforma a la LOC del Tribunal Constitucional, la inexistencia de control repa- 
rador de constitucionalidad, lo que debe ser explicitado en el texto constitucional, aunque ello, en la práctica, se deduce en una interpretación armónica y finalista de la Constitución, como del artículo $54 \mathrm{~N}^{\circ}$, inciso primero, del texto vigente de la Constitución, aunque una mayoría de magistrados del Tribunal Constitucional ha interpretado pretorianamente lo contrario generando un control de tratados inexistente en el texto constitucional. La concreción de esta primera propuesta contribuye en forma significativa a una plena coherencia del sistema constitucional con el derecho convencional internacional ratificado, considerando las normas del artículo $54 \mathrm{~N}^{\circ} 1$, inciso quinto, y del artículo $5^{\circ}$ inciso $2^{\circ}$ de la Constitución, conforme a la interpretación del Tribunal Constitucional en su fallo de 2013, los que constitucionalizan los principios pacta sunt servanda y de no oposición de obstáculos de derecho interno al cumplimiento de las obligaciones jurídicas internacionales contenidos en los artículos 26, 27 y 31.1 de la Convención de Viena sobre Derecho de los Tratados. Todo lo anterior tiene como consecuencia lógica que si eventualmente pudiera filtrarse una norma de un tratado contraria a la Constitución, el Estado no podría actuar contra ella sino a través de la desvinculación de la obligación jurídica internacional a través de la denuncia del tratado o su renegociación, si ello fuere procedente, conforme al derecho internacional.

En segundo lugar, se sugiere la incorporación al texto constitucional en forma inequívoca de los tratados internacionales de derechos humanos ratificados por Chile y vigentes, como asimismo el reconocimiento con rango constitucional de los principios imperativos de derecho internacional (ius cogens), lo que asegura el respeto y garantía de los estándares mínimos de atributos y garantías de los derechos esenciales o humanos.

En tercer lugar, se sugiere la incorporación al texto constitucional de los principios interpretativos básicos en materia de derechos humanos y fundamentales como son los de progresividad y pro homine o favor persona, los que obligan a aplicar el enunciado normativo que mejor protege los atributos y garantías de los derechos esenciales o fundamentales, sea esta la norma de derecho internacional o de derecho interno, los cuales han sido utilizados aunque no de manera sistemática por la jurisprudencia del Tribunal Constitucional.

Las modificaciones constitucionales sugeridas ya se encuentran incorporadas en diversas constituciones latinoamericanas en las últimas dos décadas, de las cuales las más recientes son la Constitución de Santo Domingo de 2010 y la reforma constitucional de 2011 a la Constitución mexicana, lo que permite la completa armonización del derecho constitucional e internacional, otorga seguridad jurídica plena a las personas sobre sus derechos y disminuyendo drásticamente el riesgo de responsabilidad del Estado por vulneración del estándar mínimo de derechos asegurados por el derecho internacional de los derechos humanos por órganos estatales nacionales.

\section{BIBLIOGRAFÍA}

Aldunate Lizana, Eduardo (2013): "La posición de los tratados internacionales en el sistema de fuentes del ordenamiento jurídico chileno a la luz del derecho positivo", en Cordero, Eduardo y Aldunate, Eduardo (edits.), El sistema de fuentes en el derecho chileno (Santiago, Editorial LegalPublishing-Thomson Reuters) pp. 83-125. 
Amaya Villareal, Álvaro Francisco (2005): "El principio pro homine: interpretación extensiva vs. El consentimiento del Estado", en Revista Colombiana de Derecho Internacional $N^{\circ}$ 5, junio, Pontificia Universidad Javeriana: pp. 337-380.

Aragón Reyes, Manuel (director) y Aguado Renado, César (codirector) (2011): Constitución, Estado Constitucional y Fuentes del Derecho. Temas básicos de derecho constitucional, Tomo I (Pamplona, Navarra, Ed. Civitas-Thomson Reuters y Ed. Aranzadi) 464 pp.

Ayala Corao, Carlos (2012): Del diálogo jurisprudencial al control de convencionalidad (Caracas, Editorial Jurídica Venezolana) 295 pp.

Balaguer Callejón, Francisco (coord.) (2012): Manual de Derecho Constitucional (Madrid, Editorial Técnos, séptima edición) 484 pp.

Bidart Campos, Germán (2001): "Las fuentes del derecho constitucional y el principio pro homine”, en Bidart Campos, Germán y Gil Domínguez, A. (coords.), El derecho constitucional del siglo XXI. Diagnóstico y prospectivas (Buenos Aires, Editorial Ediar) 557 pp.

Cea Egaña, José Luis (2012): Derecho Constitucional Chileno, Tomo II (Santiago, Editorial Universidad Católica de Chile, segunda edición actualizada) 773 pp.

Cumplido Cereceda, Francisco (1997): "Los tratados internacionales y el artículo $5^{\circ}$ de la Constitución”, en Revista Ius et Praxis, Año 2 N² 2: pp. 93-99.

Fernández GonzÁlez, Miguel Ángel (2003): "Visión prospectiva en relación a la regulación constitucional de los tratados internacionales", en Revista Ius et Praxis, Año $9 \mathrm{~N}^{\circ} 1$ : pp. 485-511.

Ferrajol, Luigi (2010): Derecho y garantías (Roma-Bari, Ed. Trotta, séptima edición) 184 pp.

Henríquez Viñas, Miriam (2007): "Improcedencia del control represivo de constitucionalidad de los tratados internacionales”, en Revista Estudios Constitucionales, año $5 \mathrm{~N}^{\circ} 1$ : pp. $119-126$

Henríquez Viñas, Miriam (2009): Las fuentes formales del derecho (Santiago, Ed. LegalPublishing) XX pp.

Henríquez Viñas, Miriam (2009a): "Improcedencia del control represivo de constitucionalidad de los tratados internacionales", en Revista Estudios Constitucionales, Año $5 \mathrm{~N}^{\circ}$ 2: pp. $121-135$.

Jimena QUesada, Luis (2013): Jurisdicción nacional y control de convencionalidad. A propósito del diálogo judicial global y de la tutela multinivel de derechos (Navarra, Ed. Thomson Reuters-Aranzadi) 174 pp.

Nogueira Alcalá, Humberto (1997): "Los tratados internacionales en el ordenamiento

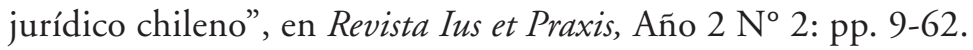

Nogueira Alcalá, Humberto (2005). "Aspectos fundamentales de la reforma constitucional 2005 en materia de tratados internacionales", en Nogueira Alcalá, Humberto. (coord.), La Constitución reformada de 2005 (Santiago, Ed. Librotecnia) 668 pp.

Nogueira Alcalá, Humberto (2006): Lineamientos de interpretación constitucional y del bloque constitucional de derechos (Santiago, Ed. Librotecnia) 413 pp.

Nogueira Alcalá, Humberto (2012): Derecho Constitucional chileno. Tomo I (Santiago, Ed. Abeledo Perrot-Thomson Reuters) 962 pp. 
Nogueira Alcalá, Humberto (2012a): El uso del derecho convencional internacional de los derechos humanos en la jurisprudencia del Tribunal Constitucional chileno en el periodo 2006-2010", en Revista Chilena de Derecho, vol. 39 N 1: pp. 149-187.

Martín Retortillo Baquer, Lorenzo (2004): La interconexión de los ordenamientos juridicos y el sistema de fuentes del derecho (Madrid, Ed. Civitas) 204 pp.

Peña Torres, Marisol (2006): "Los tratados internacionales en la jurisprudencia constitucional”, en Revista Estudios Constitucionales, Año $1 \mathrm{~N}^{\circ}$ 1: pp. 593-611.

Pérez Luño, Antonio (2011): El desbordamiento de las fuentes del derecho (Navarra, Ed. La Ley) $260 \mathrm{pp}$.

PINTO, Mónica (1997): "El principio pro homine. Criterios de hermenéutica y pautas para la regulación de los derechos humanos", en Abregú, Martín y Courtis, Christian (comp.), La aplicación de los tratados de derechos humanos por los tribunales locales (Buenos Aires, Ed. Del Puerto/CELS) pp. 163-172.

Rivera Neumann, Teodoro (2007): Los tratados internacionales y su control a posteriori por el Tribunal constitucional”, en Revista Estudios Constitucionales, Año $5 \mathrm{~N}^{\circ}$ 1: pp. 89-118.

Silva Irarrázaval, L.A. (2006): "El control de constitucionalidad de los actos administrativos en Francia y el control indirecto de constitucionalidad de la ley: la teoría de la ley pantalla”, en Revista Ius et Praxis, Año 12 N $^{\circ}$ : pp. 201-219.

Vivanco Martínez, Ángela (2006): Curso de Derecho constitucional. Tomo II (Santiago, Ediciones Universidad Católica de Chile) $551 \mathrm{pp}$.

Verdugo, Sergio (2011): “¿Control obligatorio para todos los tratados internacionales? Crítica a una propuesta inconveniente, en Anuario de Derecho Público 2010 (Santiago, Universidad Diego Portales) pp. 449 - 477.

\section{SENTENCIAS DEL TRIBUNAL CONSTITUCIONAL}

Sentencia Rol No 325, de 26 de junio de 2001;

Sentencia Rol No 346, de 8 de abril de 2002;

Sentencia Rol N ${ }^{\circ}$ 576, de 24 de abril de 2007;

Sentencia Rol No 804-07, de fecha 28 de diciembre de 2007;

Sentencia Rol No 807, de 4 de octubre de 2007

Sentencia Rol No 834, de 13 de mayo de 2008

Sentencia Rol 943-07, de fecha 10 de junio de 2008;

Sentencia Rol No No 993 y No 1152, de 2008;

Sentencia Rol N $1218-08-I N A$, de 7 de julio de 2009;

Sentencia Rol No 1288-2008, de 25 de agosto de 2009;

Sentencias Rol No 1361-09, de 2009;

Sentencias Rol No 986, de 30 de enero de 2008;

Sentencia Rol No No 821, de 1 de abril de 2008;

Sentencia Rol No No 1130, de 7 de octubre de 2008;

Sentencia Rol No 1340, de 29 de septiembre de 2009;

Sentencia Rol No 1361-09, de 13 de mayo de 2009; 
Sentencia 1415-09, de 14 de junio de 2009;

Sentencia Rol No 1432, de 5 de agosto de 2010;

Sentencia Rol No 1443, de 26 de agosto de 2010;

Sentencia No 1501, de 31 de agosto de 2010;

Sentencia Rol N 1988-11 CPT, de 24 de junio de 2011;

Sentencia Rol N 1881-10, de 3 de noviembre de 2011;

Sentencia roles No 2387-12-CPT y 2388-12-CPT acumulados, de 23 de enero de 2013. 
